\title{
Digital Story Telling of Christian Education Learning on Elementary School at Tomohon
}

\author{
Olivia C Wuwung1, Jeremia Engelita Wakas², Juanda Manullang ${ }^{3}$ \\ Institut Agama Kristen Negeri Manado \\ olivia.wuwung@gmail.com¹, engelita.wakas@gmail.com²,manullang.juanda@gmail.com³
}

\begin{abstract}
This study aims to identify the effect of digital storytelling on student learning outcomes in Christian Education Learning at Elementary School in Tomohon. Many previous studies have discussed the use of digital storytelling in learning in the classroom at both elementary and tertiary levels. There is no previous research discussing digital storytelling in Elementary Christian Education Learning in (PAK). The method used in this study is quantitative. Pre-test and post-test were carried out in the experimental class and the control class then tested using the t-test. The results showed the influence of digital storytelling on student learning outcomes in Christian Education Learning. From the results of the study, it can be concluded that digital storytelling is one of the learning media innovations in Christian Education Learning in disruptive era that affects the student learning outcomes.
\end{abstract}

Keywords: Digital Story Telling, Christian Education Learning.

\section{Introduction}

Technological developments in this disruptive era require teachers to make creative innovations in classroom learning. Go along with the 2013 curriculum purpose, teachers are entailed to invent a creative innovative learning situation using appropriate and effective learning aids. In this case, the teacher as an educator must be able to develop innovative learning media based on the curriculum, the development of student needs, and information technology development. One of the principles in the learning process standard is the use of information and communication technology to improve the efficiency and effectiveness of learning (Permendikbud Number 103 of 2014).

"What is digital storytelling? Briefly, it tells stories with digital technology. Digital stories are building narratives from the cyberculture stuff" (Alexander, 2011: 3). Digital storytelling is a process that blends media to enrich and enhance the written or spoken word - multimedia tales are the modern expression of an ancient art (Frazel, 2010, p.9). In the context of teaching and learning, Digital Storytelling is one of the learning methods that tries to combine several skills, namely listening skills, speaking skills, writing skills, and the skills to operate programs that make use of the computer and technology development (Muhyadi, et.al,2010). It is supported by the statement of Heriyana and Maureen (2014) who cite an article on the website of the University of Houston that learning using Digital Storytelling can improve some student skills, namely research skills, writing skills, skills in using technology, presentation skills, interviewing skills, problem solving skills, and skills in judging something. Essentially, digital storytelling is a practice combining narration/personal stories with multimedia all images, audio and text (Banaszewski, 2005). 
Christian Education (PAK) is a conscious, systematic and continuous effort to nurture Christian faith of the members of the community in various age categories, all family, faith community, and school contexts (Nuhamara, 2018). According to Thomas Groome cited from the journal of Daniel Nuhamara (2018), the nature and the purpose of PAK requires us to advance individual cognition as a critical reflective, dialectic and dialogic process that drives discourse, and that we need to expand our attention beyond mere cognition. Werner C. Graendford (1976) in Children Christian Education book (Indahyani, 2014, p. 18) states that children Christian Education is a process of teaching and learning based on the Bible, centered on Christ and fully depended on the Holy Spirit in guiding children to become mature disciples of Christ.

Syamsu Yusuf (2004) in his book states that the elementary school age is the configuration period of religious values as the continuation of the previous period. The religious quality of children will be greatly influenced by the process or formation or education received. As stated by Yusuf (2004), religious education in primary schools has a crucial role. Therefore, religious education (teaching, habit forming, and instilling values) in primary schools must be a concern of all the parties involved in this education.

Christian and Moral Education subject become one of the subjects of the Elementary School students affected the student character building. Eliman (2017) argued that religious education and moral guidance in schools is one of the principles of fostering student positive attitudes and can successfully shape child's personality. Lesson comprehension is important to be understood to support the formation of good character. Accordingly, it is important to be supported by innovative and creative learning media in this disruptive era. Rusman (2013: 172) stated that the benefits of learning media in learning process are as follows, (a) it grows student motivation; (b) students master the learning objectives better; (c) learning methods will be more varied; (d) students do more learning activities.

According to the results of the pre-research conducted by interviews with the PAK teachers in SD GMIM 1 Tomohon, previously they had never heard the term digital storytelling as a medium in PAK learning. In addition to the unavailability of facilities such as laptops and LCDs, teachers are still more comfortable using conventional methods, namely lectures, questions and answers and discussions. However, there are some problems with the method used, including students still do not understand the material given marked by when the teacher asked, some students still do not know yet, and students look sleepy and lack of enthusiasm when the lesson delivered using conventional methods.

In contrast to the pre-research, the PAK teachers in Tomohon II Public Elementary School had heard the term digital storytelling before but they rarely used it because of the limited tools. However, they admitted that using digital storytelling resulted in students being more interested and learning quickly marked by student enthusiasm receiving material using digital storytelling.

In this study, SD GMIM I Tomohon is the digital storytelling experimental class and SD Negeri 2 Tomohon as the control class with no digital storytelling. In the experimental class, a pretest is carried out before displaying the Bible story related to the lesson. After that, the writers introduced digital storytelling to teachers and students by showing in class one of the Bible stories related to the lesson using digital storytelling. Then, a posttest was performed with the same questions to see the effect of using digital story telling. In the same way with the control class, pretest and posttest were conducted before and after the lesson delivery without using digital storytelling. 


\section{Literature Review}

The previous research related to this study is a study conducted by Safitri Yosita Ratri (2018) entitled Digital Storytelling in Social Education Learning at Elementary Schools in the journal of Children Education and Character Volume 1, Number 1. The result shows that digital storytelling can improve student social competence and it plays a role in improving not only the cognitive aspects but also the affective and psychomotor aspects of students as their provisions in the future. The difference between this study and the one performed by Safitri Yosita Ratri is the method used.

The other research related to this study was conducted by Wina Heriyana and Irene Y.Maureen (2014) entitiled The application of digital storytelling method on the idol storytelling skill of Indonesian language subject to the seventh grade students in SMP Negeri 1 Kedamean Gresik in student journal education technology volume 5, number 2. This study showed that the application of digital storytelling through observation and interviews improve student learning outcomes.

Both studies above discuss the Digital Storytelling usage. The difference with this study is that the subjects is PAK and the methods is the quantitative approach.

\section{Method}

The research method used is a quantitative approach. This study was conducted in two elementary schools in Tomohon, namely SD GMIM I Tomohon and SD Negeri II Tomohon, to the fifth grade students in Christian and moral education subject. Data collected on November 29, 2019. The population in this study was the 27 Christian students in grade V at SD GMIM 1 Tomohon and the 29 Christian students in grade V at SD Negeri II Tomohon. It uses the experimental method with one control class and one experimental class, where in the learning process of Christian and moral education subject in the control class, SD Negeri II Tomohon, digital storytelling did not use. While the experimental class, SD GMIM I Tomohon, used digital storytelling.

Furthermore, statistical analysis is performed to determine whether the use of digital storytelling affects student learning outcomes. Data collection techniques used in a written test form of 20 essay questions to assess learning outcomes in the form of pre-test and post-test. Quantitative data is in initial and final tests scores forms analyzed with the following steps.

\subsection{Conducting Prerequisite Tests}

The prerequisite test is the pretest and posttest average normality tests performed with SPSS 23.0, the Shapiro-Wilk test, with the test significant level $\alpha=0,05$, if the significance obtained $>\alpha$, then the data distribution is normal. However, when the significance obtained $<$ $\alpha$, it means the data is not normally distributed. In addition, a homogeneity test was done between the pre-testand the post-test variances. TheHomogeneity test results can be found by comparing the significance value on Sig. in the Test of Homogeneity of Variance table with the test significance level $\alpha=0,05$. The criteria is if the significance obtained $>\alpha$, then both variances are the same (homogeneous). Whereas if it obtained $<\alpha$, then the two variances are different. 


\subsection{Uji Normalitas dan Homogenitas}

If the results of the normality and homogeneity tests show that the data are normally distributed and homogeneous, then the parametric test is continued, that is, the average of the two different test with t-test). The type of t-test used is the Independent sample t-Test, which is done with SPSS 23.0 for window. The decision making criteria are determined based on the significant value (sig), if the sig value is $>0.05$ then Ho is accepted (there is no relationship), and if the sig value is $<0.05$ then Ho is rejected (there is a relationship). The t-test formula used is:

Description:

$$
t=\frac{\bar{x}-\bar{y}}{\sqrt{s^{2} x y\left(\frac{1}{N x}+\frac{1}{N y}\right)}}
$$

$$
\begin{aligned}
& \mathrm{t}=\text { Test value } \mathrm{t} \\
& \mathrm{x}=\text { Average N-gain pretest } \\
& \mathrm{y} \quad=\text { Posttest N-gain average value } \\
& \mathrm{s} 2 \mathrm{xy}=\text { Standard deviation of squares } \\
& \mathrm{Nx}=\text { Number of samples of counter class } \\
& \mathrm{Ny}=\text { Number of samples of experimental class }
\end{aligned}
$$

\subsection{Hypothesis Testing}

The hypothesis is statistically tested using the t-test formula above, to determine the $t$ value of the table statistics, a significant level of $\alpha=0.05$ is used with free degrees $\mathrm{dk}=(\mathrm{nk}-1)$, with the test criteria accepted Ho If $\mathrm{t}$ arithmetic $<\mathrm{t}$ table, and accepted $\mathrm{Ha}$ if $\mathrm{t}$ arithmetic $\geq \mathrm{t}$ table.

\section{Results and Discussion}

This study was conducted in Elementary Schools in Tomohon, namely SD GMIM 1Tomohon and SD Negeri 2 Tomohon, with the subject of the study is the Christian students in grade $\mathrm{V}$ on Christian and moral Education. There were 29 students in the control class and 27 students in the experimental class. This study discusses two variables consisting of one independent variable, namely Digital Storytelling in PAK learning (x), and therelated

\begin{tabular}{|c|c|c|c|c|}
\hline Class & Average & Normality & Homogeneity & Significance \\
\hline Eksperimen & 13,93 & Sig: $0,174>0,05$ & Sig: $0.493>0,05$ & $\begin{array}{l}\mathrm{t} \text { hit }<\mathrm{t} \text { table } \\
0,570<1,672\end{array}$ \\
\hline Kontrol & 13,85 & Sig: $0,189>0,05$ & & $\begin{array}{l}\text { Sig }(2-\text { tailed }) \\
0,185>0,05 \\
\text { Tidak Berbeda } \\
\text { Nyata }\end{array}$ \\
\hline
\end{tabular}
variable, namely learning outcomes (y).

The $\mathrm{T}$ test was performed to determine the effect of digital storytelling in Christian education and moral learning on student learning outcomes. The $\mathrm{T}$ test is done only once to find out the similarities in the post-tests of experimental and control classes.

Table 1. The Average Pretest Value of Student Learning Outcomes in he Control and the Experimental Classes. 
The analysis of the pretest ability in the experimental class and the control class as seen in Table 1 . The analysis result of table 1 shows the average pretest value of the students in the experimental class is 13,93 and in the control class is 13,85 . It states that the ability of both classes is still low. The T-test results describe that t-hit $<$ t-table $0,570<1,672)$ and Sig $(2$ tailed) $0,185>0,05$ mean that there is no significant difference between pretest of the control class and the experimental class, meaning the initial ability of the students in the experimental class and the control class are the same.

Table 2.The Average Posttest Value of Student Learning Outcomes in the Control and Experimental Classes.

\begin{tabular}{lllll}
\hline Class & Average & Normality & Homogeneity & Significance \\
\hline Eksperimen & 14,04 & Sig: $0,317>0,05$ & Sig: $0.888>0,05$ & t hit $<$ t table \\
& & & & $0,745<1,672$ \\
Kontrol & 13,81 & Sig: $0,515>0,05$ & & Sig $(2-$ tailed) \\
& & & & $0,574>0,05$ \\
& & & Significantly \\
\hline
\end{tabular}

While the analysis results of the student learning outcomes final ability in the experimental class and the control class are in table 2 . The results in Table 2 shows that the average posttest value of students in the experimental class is 14,04 and in the control class is 13,81 . The Significance results at the level of $\alpha=0,05$ with the t-test and the results is t-hit $>\mathrm{t}$-table $(4,335>1,672)$ with $\mathrm{Sig}$ (2-tailed) $0,574>0,05$. It shows that the data is significant, meaning that there is an influence on the use of Digital Storytelling to student learning outcomes. The use of digital storytelling aid influences student learning outcomes because digital storytelling is more interesting and is easier to be understood by students.

\section{Conclusion}

There is a significant influence of the digital storytelling usage on learning outcomes in Christian Education learning of the grade V students in Christian and moral Education subject at SD GMIM I Tomohon as experiment class. There is no a significant influence on learning outcomes in Christian Education Learning of the grade fifth students in Christian and moran Education subject at SD Negeri II Tomohon as control class.

According to the results of the study, it can be concluded that there is a influence of the digital storytelling usage on learning outcomes in Christian Education Learning. Digital storytelling becomes one of the learning media in Christian Education Learning in this disruptive era.

\section{References}

[1] Alexander, B: The New Digital Storrytelling Creating Naratives With New Media. Oxford England, Praeger (2011)

[2] Banaszewski, Thomas M: Digital Storytelling Supporting Digital Literacy In Grades 4-12 (2005)

[3] Eliman:. Model Bimbingan Dalam Pendidikan Agama Kristen Terhadap Pembentukan Moral Anak Didik Usia 6-8 Tahun. Epigraphe: Jurnal Teologi dan Pelayanan Kristiani Volume 1, Nomor 2 (2017) 
[4] Frazel, M.: Digital Storytelling: Guide for Educators.International Society Society for Technology in Education (ISTE), Wahington DC (2011)

[5] Heriyana, W dan Maureen, Y: Penerapan Metode Digital Storytelling Pada Keterampilan Menceritakan Tokoh Idola Mata Pelajaran Bahasa Indonesia Siswa Kelas VII di SMP Negeri 1 Kedamean, Gresik. Jurnal Online Universitas Negeri Surabaya (2014)

[6] Indahyani, Ii V: Pendidikan Agama Kristen Anak. Garuda Mas Sejahtera, Surabaya (2014)

[7] Muhyadi, et al: Pelatihan Pembuatan Media Digital Story Telling (DST) Dalam Rangka Pengembangan Media Berbasis ICT untuk Pembelajaran Kelas SBI di SMP 1 Karangmojo. Pengabdian kepada masyarakat Prioritas Fakultas. Universitas Negeri Yogyakarta (2010)

[8] Nuhamara, D: Prioritizing Character Dimensions in Christian Religious Education. Jurnal Jaffray Vol. 16, no. 1 (2018)

[9] Permendikbud Nomor 103 tahun 2014 tentang Pembelajaran pada Pendidikan Dasar dan Pendidikan Menengah. Salinan Lampiran Permendikbud RI

[10] Ratri, S. Y: Digital Storytelling Pada Pembelajaran IPS di Sekolah Dasar. Jurnal Pena Karakter Volume 1 Nomor 1 (2018)

[11] Ruseffendi, E.T: Statistika Dasar Untuk Penelitian Pendidikan. IKIP Bandung Press, Bandung (1998)

[12] Rusman, K.D. \& Riyana, C: Pembelajaran Berbasis Teknologi Informasi dan Komunikasi. Rajawali Pers, Jakarta (2013)

[13] Yusuf, Syamsu: Psikologi Perkembangan Anak dan Remaja. Cetakan ke-4. Remaja Rosdakarya, Bandung (2004) 